\title{
Assessment of Influential Causes of Construction Project Delay in Malaysian Private Housing from Developer's Viewpoint
}

\author{
M.A. Othuman Mydin ${ }^{1}$, N. Md Sani ${ }^{2}$, N.A Agus Salim ${ }^{3}$, N. Mohamed Alias ${ }^{4}$ \\ ${ }^{1,2,4}$ School of Housing, Building and Planning, Universiti Sains Malaysia, 11800 Penang, Malaysia \\ ${ }^{3}$ Faculty of Architecture, Planning and Surveying, UiTM Perak, Seri Iskandar Campus, 32610, Seri \\ Iskandar, Perak, Malaysia
}

\begin{abstract}
Project delay in the construction industry is a universal or large-scale observable fact affecting not only the construction industry but the overall economy of countries too. The objective of this study is to evaluate and identify the causes and consequences of project delays in the private housing development projects in Malaysia and the remedies that can minimize these delays. An online questionnaire survey has been carried out to collect the data and this included 76 respondents from multiple developers' companies around Malaysia. From the survey, a total of 28 causes and 6 consequences of project delays had been identified from four different factors of delays; such as client factors, consultant factors, contractor factors and external factors, by which the contractor factor being the major contributor to this problem. The top ten causes of the delays are due to weather conditions, poor site conditions, poor site management, incomplete documents, lack of experience, financial problems, contract modifications, delay in approving of major variations, contractor coordination problem with other parties and construction mistakes and defective works. The consequences of the delays would contribute to time overrun, cost overrun, different in opinions, negotiations, legal actions and total abandonment.
\end{abstract}

\section{Introduction}

Project delay can be defined as an incident that causes extended time to complete all or part of a particular projects. Delay can also be defined as the time overrun, either ahead of the date for project completion specified by the contract or further than the extended contract period where an addition of time has been granted [1]. The project delay in the construction industry is a universal or large-scale observable fact affecting not only the construction industry but the overall economy of a country as well [2].

Project delay involves manifold multifaceted issues all of which are perpetually of decisive magnitude to the parties to the construction contract. These issues concern right to recuperate costs of the project delay or the need to extend the project with the substantial right to recovery costs for adjustments to the contract schedules [3]. 
Another significant heritage building fire mishap happened on 11th December 2008, when fire destroyed 7 shops [7]. In Malacca, similar fire case reported to take place on $7^{\text {th }}$ August 2012, whereby a century old Lido theatre, had burnt down to ashes [8]. The blaze, which occurred just past midnight, destroyed most of the structure of the city's landmark in Jalan Kee Ann. Although the building no longer housed the theatre but a supermarket instead, but its name was retained due to its historic value. The fire demolished everything in it, causing severe loss to the owner [9].

Recently fire outbreak also reported in Jalan CY Choy, Georgetown. On February 24th, 2013, a row of 10 shop houses went down in flames on the Chap Goh Meh celebration in the evening. It was fortunate that no one was injured in the incident. The damages were estimated to be more than RM1 million. According to Beach Street fire station head, Ismail Mohd Zain, six engines from nearby fire stations rushed to the scene after a distress call was received at $7.55 \mathrm{pm}$. According to Ismail, the fire raged as the pre-war properties were mainly constructed from wood, causing the fire to spread quickly [10]. Efforts should be made to improve fire protection and resistance at historic buildings to make certain that they are safe from the danger of fire with the concern of preserving the buildings' fabric without destroying or changing the features of existing buildings $[11,12]$. In order to complete this research, 4 heritage religious buildings in Penang will be chosen as samples to carry out further investigation.

One of the main objectives and policies of any public or private sectors dealing with the implementation of project is to upgrade the projects performance process, through reduction of costs, completion of the construction project within their contract sum and time limit and improve quality. Private housing project delays are often caused by circumstances that create barriers to launch and further implementation of project activities [4]. When project delays are unexpected, they are hardly manageable and have rather negative impacts on the project activities and outcomes [5]. An unexpected delay will extends the overall duration of project activities and entails an increase in project costs [6]. It produces time-associated cost effects that will increase the resource consumption and will require extra time upon reaching project success [7].

In the private housing sector a developer can just be a project owner or both the owner and contractor of a development project itself. In either capacity, a developer has certain requirements that need to be addressed clearly in the contract document [8]. If this is done, the probability of a successful completion of the project is increased. If the preliminary step is omitted, the chances of delay and disagreement will heightened [9].

It is knowable that various studies and researches had been conducted on this subject matter beforehand. Most of them were focused on explaining the causes, which would be accommodating to guide practitioners to identify possible measures for mitigating against delays in construction project. Delays in construction projects risen the displeasure to all the parties involved and the main role of the project manager is to make sure that the projects are completed within the budgeted time and cost [10]. Despite many recommendations being introduced after researches and studies being done, the projects delays is still the major problem in constructions industry up to day. The main purpose of this study is to identify the factors of delays and their effect on project completion. This study takes an integrated approach and attempts to analyze the effect of specific causes on specific effects.

\section{Methodology}

The research methodology will be described and explained based on the objectives of this study. Two approaches will be used throughout this study to gather reliable and related data. Those approaches are literature review and questionnaire survey that focus on clients, consultants and contractors. The literature review was done through engineering journals, articles and books. By referring to the previous literature, the information from the causes of construction projects delays, consequences of construction projects delays, and the method of minimizing the delay would be used 
to develop the questionnaire survey in order to collect data from the targeted respondents. An online questionnaire has been developed to know the perspectives from several developers in Malaysia. 28 causes have been identified from the literature review and been divided into four factors that is client factors, contractor factors, consultant factors and external factors. Next part is the consequences of project delays. A number of six consequences of delay also been identified that is the time overrun, cost overrun, opinion differences, negotiations, legal actions and total abandonment.

This research is based on purposive sampling technique, as the alternative choice of probability sampling is not considered due to limited time and resources. The researchers will make contact with potential respondents based on the statistic of private housing delay project all around Malaysia that have been given by the Ministry of Housing and Local Government of Malaysia. Based on the information that been gather from them, around 220 developers in the private housing project around Malaysia that have some delays problems in their projects and a total of 220 sets of questionnaire were distributed for this survey but only 76 sets of questionnaire that have been answered.

\section{Data Analysis and Discussion}

\subsection{Causes of Delays}

The data collected from the questionnaire was analyzed from the perspective of the developers. Every cause of delays based on the client factor, contractors factor, consultants factor and externals factor was computed for overall analysis. The mean score was computed for each cause to identify the most significant causes and later the causes of delays were ranked based on the mean score. Based on Table 1, the ranking that been given to each cause of delays will be used to identify the most important factors or causes of delay in Malaysian private housing industry. Therefore based on the ranking of the causes of delays from Figure 1, the top 10 causes of delay in private housing projects have been identified. The highest causes of delays are as follows:

(1) The weather conditions on the site (external factors) whereas the mean score calculated at 4.41. This shows that unpredictable weathers conditions can really give a big effect to the construction's progress whether the project proceeds quickly or slowly. This implies that the environment is a very important factor in construction project.

(2) Poor site condition (mean value score $=4.26$ ) can cause delay in private housing projects. A poor site condition will decrease the productivity on the site.

(3) The poor site management of the contractor (mean value score $=4.09$ ),

(4) Incomplete documentation by the consultant (mean value score $=4.05$ ). The consultant has full authority to make changes, correct the mistakes in the drawings and the discrepancies in the contract document on behalf of the client.

(5) Lack of experience on the part of consultant site staffs (managerial and supervisory personnel) (mean value score $=3.99$ ) some of the consultant site staffs do not have enough experience in the construction industry. Some problems in the design cannot be detected until the contractor enquired about them in the construction.

(6) Financial problems (mean value score $=3.97$ ) of the contractors are the cause of delay in housing projects and have been at the six ranked in this analysis based on the mean score value that is 3.97. This delay happen because when contractors received advanced or monthly payment from their clients, most of them may use the money to finance other urgent or more profitable projects.

(7) Contract modifications (replacement and addition of new work and changes in specifications) by the client(mean value score $=3.93$ ),

(8) Delay in approving major changes in the scope of work by the consultants (mean value score= 3.93). It is time consuming and complex process for consultants to approve documents submitted by the contractors (e.g. method statement or specifications). 
(9) Contractors coordination problems with other parties (mean value score $=3.92$ ) can cause delay. A total of $76 \%$ of the respondent agree with this type of delays. The contractors have to frequently communicate with the other project participants.

(10) Constructions mistakes and defective work (mean value score $=3.88$ ) . With high demand of workforce in the local constructions market,, majority of the labours are from other countries like Indonesia, Myanmar, Bangladesh and others that are without adequate training. This often leads to poor workmanship.

Table 1: Causes of Delays in Private Housing Projects in Malaysia

\begin{tabular}{|c|c|c|c|c|c|c|c|}
\hline \multirow[t]{2}{*}{ Description } & 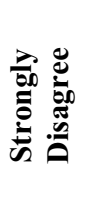 & 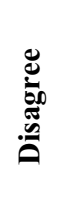 & 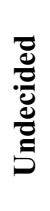 & 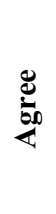 & 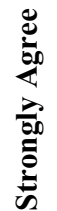 & \multirow[t]{2}{*}{ 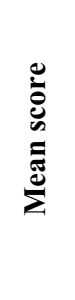 } & \multirow[t]{2}{*}{ 气્ } \\
\hline & 1 & 2 & 3 & 4 & 5 & & \\
\hline \multicolumn{8}{|c|}{ CLIENT FACTORS } \\
\hline Contract modifications & 0 & 4 & 6 & 57 & 9 & 3.93 & 7 \\
\hline Slowness in decisions making & 1 & 12 & 1 & 54 & 8 & 3.74 & 17 \\
\hline Financial problem & 2 & 14 & 1 & 44 & 14 & 3.67 & 20 \\
\hline Lack of coordination with the contractor & 2 & 20 & 0 & 49 & 5 & 3.46 & 24 \\
\hline Lack of working knowledge & 13 & 22 & 1 & 38 & 2 & 3.05 & 25 \\
\hline \multicolumn{8}{|c|}{ CONTRACTORS FACTORS } \\
\hline Poor site management & 0 & 3 & 2 & 51 & 19 & 4.09 & 3 \\
\hline Financial problem & 2 & 6 & 1 & 50 & 17 & 3.97 & 6 \\
\hline Coordination problem with other & 0 & 6 & 3 & 58 & 9 & 3.92 & 9 \\
\hline Construction mistakes and defective work & 0 & 4 & 1 & 66 & 4 & 3.88 & 10 \\
\hline Delay in delivery of material to site & 0 & 7 & 0 & 65 & 4 & 3.87 & 11 \\
\hline Low productivity of labour & 0 & 11 & 1 & 57 & 7 & 3.79 & 15 \\
\hline Shortage of material on site & 0 & 11 & 0 & 60 & 5 & 3.77 & 16 \\
\hline Poor skills of labour & 0 & 11 & 2 & 59 & 3 & 3.67 & 21 \\
\hline Shortage of site labour & 0 & 14 & 6 & 52 & 4 & 3.61 & 22 \\
\hline \multicolumn{8}{|c|}{ CONSULTANTS FACTORS } \\
\hline Incomplete documents & 0 & 2 & 1 & 59 & 13 & 4.05 & 4 \\
\hline Lack of experience on the part of consultant site staff & 0 & 5 & 3 & 51 & 16 & 3.99 & 5 \\
\hline Delay in approving major changes in the scope of work & 0 & 7 & 2 & 51 & 15 & 3.93 & 8 \\
\hline Lack of experience on the part of consultant & 0 & 5 & 3 & 57 & 9 & 3.84 & 12 \\
\hline Poor communication and coordination & 1 & 9 & 2 & 57 & 6 & 3.72 & 19 \\
\hline Absence of consultant's site staff & 4 & 24 & 13 & 32 & 2 & 2.99 & 26 \\
\hline \multicolumn{8}{|c|}{ EXTERNAL FACTORS } \\
\hline Weather conditions on the site & 0 & 0 & 4 & 42 & 31 & 4.41 & 1 \\
\hline Poor site conditions & 0 & 2 & 4 & 47 & 24 & 4.26 & 2 \\
\hline Delay in manufacturing building material & 0 & 15 & 2 & 45 & 15 & 3.83 & 13 \\
\hline Changes in laws and regulations & 0 & 5 & 9 & 57 & 5 & 3.81 & 14 \\
\hline Transportation delay & 0 & 8 & 7 & 59 & 2 & 3.72 & 18 \\
\hline Delay in performing final inspection and certification & 0 & 15 & 6 & 53 & 3 & 3.62 & 23 \\
\hline Lack of materials on the market & 3 & 38 & 3 & 30 & 3 & 2.93 & 27 \\
\hline Lack of equipment and tools on the market & 3 & 40 & 3 & 28 & 3 & 2.88 & 28 \\
\hline
\end{tabular}




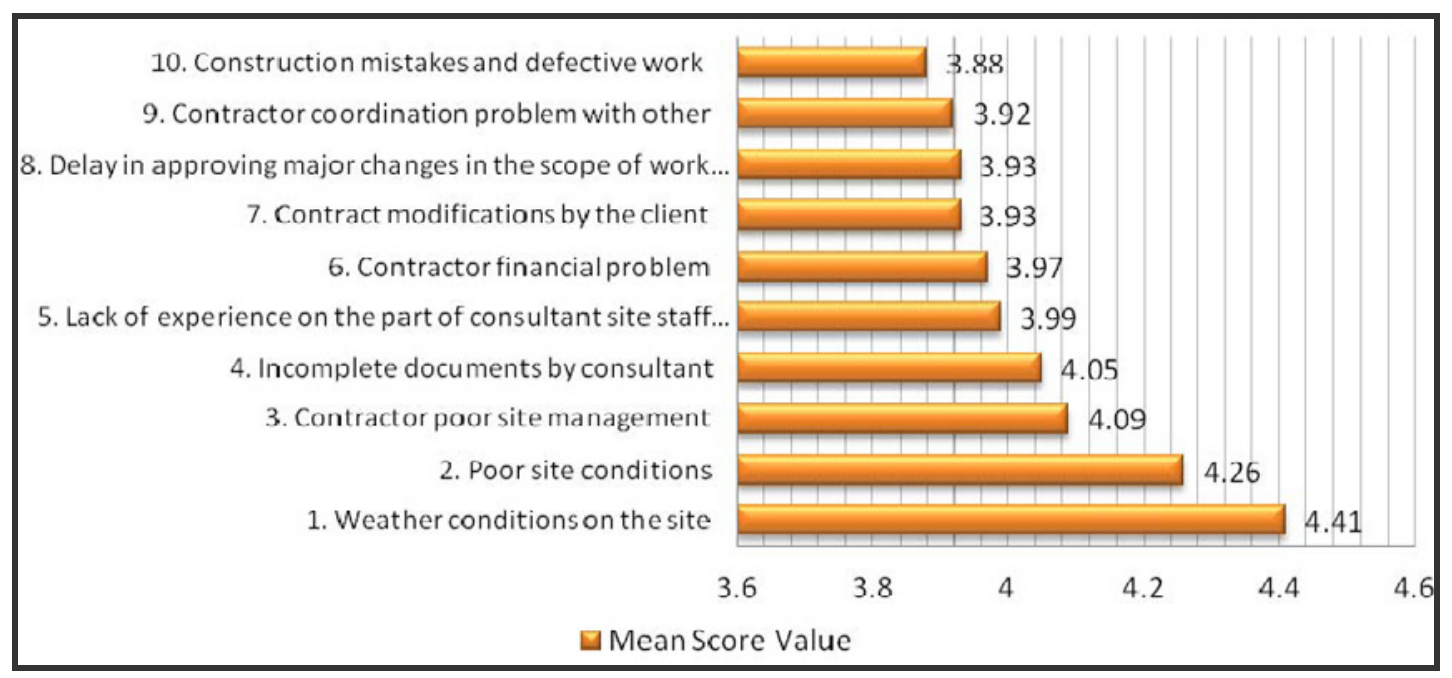

Figure 1: Top 10 Causes of Private Housing Project Delays in Malaysia

\subsection{Effects of Delays}

Based on Table 2, (1) time overrun and (2) cost overrun was the top two effects of the project delays in the private housing construction. Based on Table 5, time overrun (mean value score $=4.43$ ) are one of the highest consequences of delays. The time overrun happens when the construction process is delayed and the time of the construction process become longer than expected. Client and contractor related factors of delay are responsible for time overrun. At least half of the causes of project delays contribute to the time overrun in the construction project such as clients' hesitancy in making decision, construction mistakes and defective works, shortage of materials at sites, delay in delivery materials to site, weather conditions, and delay in manufacturing building materials and so on. Based on Fig. 2, a total of $61 \%$ of respondent agreed and $38 \%$ strongly agreed that cost overrun is the second highest rank in occasions of delays, with mean around 4.40. The cost overrun happens because of contractual factors such as contract modifications (replacement and addition of new work and changes in specifications), poor communications and site management, lack of working knowledge of the parties involved. The third consequences of delay that been ranked based on the respondent opinion is (3) opinion differences or better known as disputes. The mean score for this consequence is about 4.01 and $79 \%$ of the respondents agree difference in opinion are one of the consequences of delay in private housing industry.

Disputes frequently arise as a result of delays and all parties involved should bear the responsibility for it. A combination of environmental and behavioral factors can lead to construction disputes. Projects are usually long-term event with high uncertainty and complexity, and it is impossible to resolve every detail and foreseen contingency at the outset. (4) Negotiation (mean value score $=3.82$ ) is at the fourth rank in the analysis. Figure 2 shows that $78 \%$ of the respondents agreed negotiations can lead to consequence of delay in the project. The client's related factors and contractual relationship creates disputes and leads to be settled by negotiation, which involves third party to settle issue out of the courts.

Therefore if any of the parties do not accept the result made by the mediator, they can appeal the result that been made with the arbitrator. Negotiation is a complex process that mainly used to resolve conflicts and disagreements. Negotiation play a important part in resolving claims, prevent disputes and keep a good relationship between the project participants but the long period of negotiations may lead to the consequences of delay in private housing projects. Next consequences of delays is (5) legal actions (mean value score $=3.56$ ) or also known as litigation are at the fifth rank with a total of $66 \%$ of the respondents agreed to it. Contract disputes that lead to the construction litigation sometimes 
involve only small issues, such as non-payment, conditions of the work or deadlines of the projects, and often involve just two parties; the appointed contractor and a subcontractor. Sometimes, the contract disputes are complex and involve claims about the quality and scope of work performed by the contractor or matters pertaining to clauses in the contract agreements. These are likely to include additional parties, such as the bank and suppliers. Construction litigation involving negligence often centres on discoveries by client during or after the construction process. These discoveries will sometimes led to legal action against the contractor based on claims of poor quality of materials, improper site investigations and problems on the structural engineering.

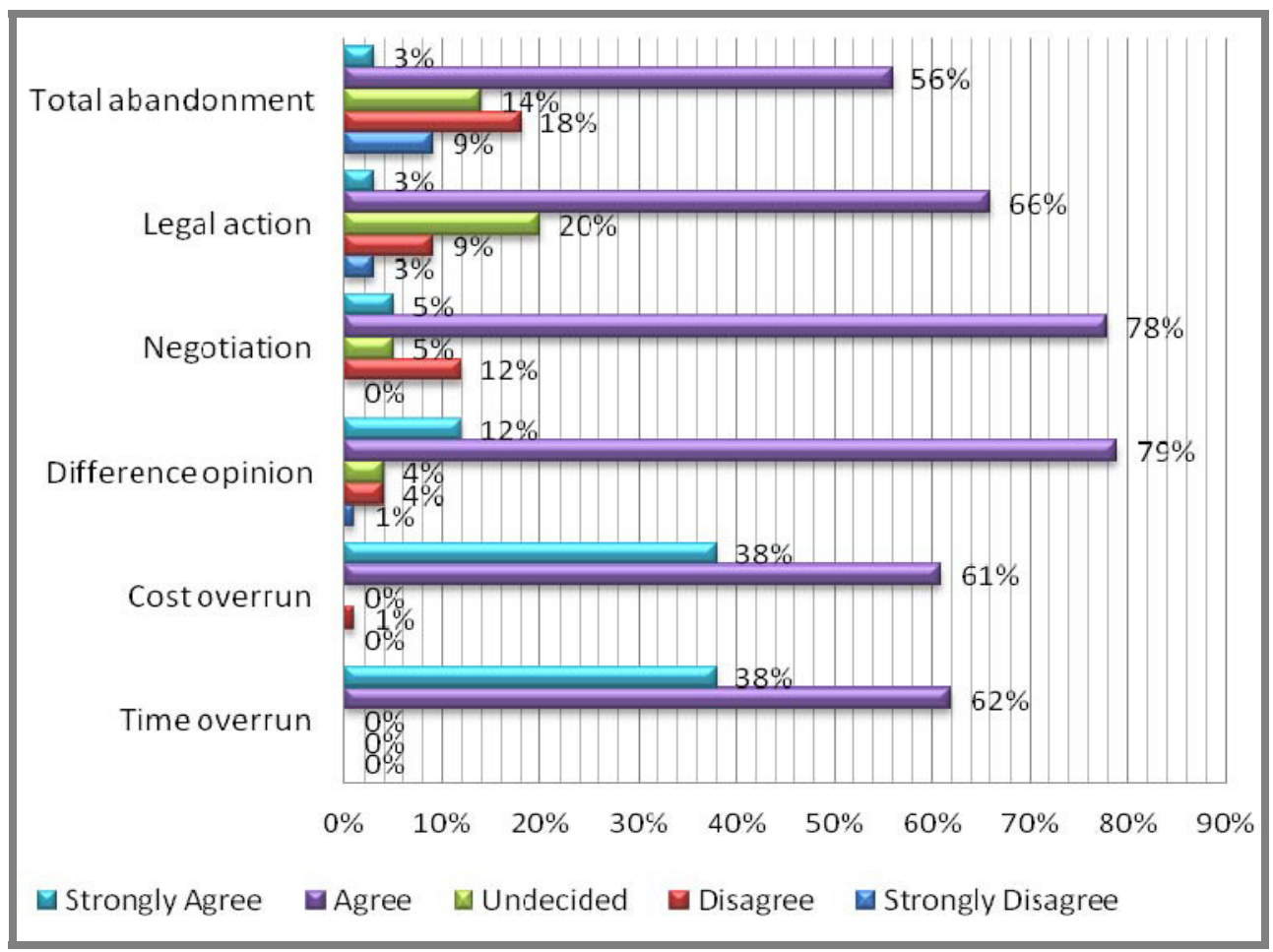

Figure 2: Consequences of Private Housing Project Delays

The last consequence of delay is the (6) total abandonment (mean value score $=3.30$ ). The four factors which are the client factors, contractor factors, consultant factors and external factors contribute to total abandonment. There are about $56 \%$ of respondents agreed, another $18 \%$ disagreed with it and another $14 \%$ of the respondents stated that they are undecided. Total abandonment happened because of the financial problem of the client or the contractor as the cash flow problems may lead to disability to proceed with the construction process.

Table 2: Consequences of Private Housing Projects Delays

\begin{tabular}{|c|c|c|c|c|c|c|c|}
\hline \multirow{2}{*}{ Description } & $\begin{array}{c}\text { Strongly } \\
\text { Disagree }\end{array}$ & Disagree & Undecided & Agree & $\begin{array}{c}\text { Strongly } \\
\text { Agree }\end{array}$ & $\begin{array}{c}\text { Mean } \\
\text { Score }\end{array}$ & Ranked \\
\cline { 2 - 7 } & 1 & 2 & 3 & 4 & 5 & & \\
\hline Time overrun & 0 & 0 & 0 & 48 & 29 & 4.43 & 1 \\
\hline Cost overrun & 0 & 1 & 0 & 47 & 29 & 4.40 & 2 \\
\hline Difference opinion & 1 & 3 & 3 & 61 & 9 & 4.01 & 3 \\
\hline Negotiation & 0 & 9 & 4 & 60 & 4 & 3.82 & 4 \\
\hline Legal action & 2 & 7 & 15 & 50 & 2 & 3.56 & 5 \\
\hline Total abandonment & 7 & 14 & 11 & 43 & 2 & 3.30 & 6 \\
\hline
\end{tabular}




\section{Recommendations}

Some recommendations are made to minimize the project delays in private housing project. The recommendations are:

i. Proper planning before commencement of the project.

ii. Approval \& confirmation of design concepts, construction drawings, materials selections, logistic plannings \& etc prior to construction stage.

iii. Improvement in communication, e.g. regular \& fruitful meeting \& site walk with relevant parties in order to solve problem in time.

iv. Effective control and monitoring of site workers, to improve productivity.

v. New rules and regulations (District Office) should be set and conveyed to the developers/contractors as soon as possible so that the developers/contractors are aware of the changes in the rules and regulations.

vi. Client to stick to original plans and to allocate adequate budget for any contract modifications.

vii. Site management \& proper remuneration / compensation on time is important to avoid the project delay.

viii. Close monitoring of the work progress.

ix. Counter check the accuracy of work progress data with actual physical completion versus cost expended.

x. Propose "Bonus" scheme for early completion.

xi. Effective planning and scheduling would overcome the problem.

\section{Conclusion}

The first objective of the study is to identify the contributing factors of project delays in Malaysian private housing based on developer's perspective has been identified. A total of 28 factors that causes delays were identified. The top ten major factors that contributed to the causes of delays were weather condition, poor site condition, poor site management of the contractor, incomplete documents from the consultant, lack of experiences on the part of the consultant site staff(managerial and supervisory personnel), contractor financial problem, contract modification by the client, delay in approving major changes in the scope of work by the consultant, contractor coordination problem with other parties and lastly is contractors construction mistakes and defective work. The factors were divided into four groups based on the causes of delays. Group of contractor factors delays was ranked the most significant groups that cause delays, followed by group of consultant factors delay, consultant related delays, client factors delay, and external delays. The second objective of this research was to study and analyze the consequences of project delays in Malaysian private housing based on the developer's point of view. There are six factors that had affect delays in private housing project which includes: times overrun, cost overrun, difference opinion or dispute, negotiation or arbitration, legal action or litigation and total abandonment. From the analysis that has been done it shown that the time overrun and cost overrun were two most frequent consequences of delays in construction project. Method of minimizing the project delays have been recommend in order to reduce the project delays in private housing projects.

\section{References}

1. Aibinu, A.A., G.O. Jagboro, 2002. The effects of construction delays on project delivery in Nigerian construction industry. International Journal of Project Management, 20 (8): 593-599

2. Chauhan, K.A., N.C. Shah, V.R. Venkata, 2008. The Analytic Hierarchy Process as a DecisionSupport System in the Housing Sector: A Case Study. World Applied Sciences Journal, 3: 609613. 
3. Annamoradnejad, R., A. Zarabi, 2011. The Qualitative and Quantitative Changes of Housing in Iran (1966-2006). World Applied Sciences Journal, 15: 350-358.

4. Abu Bakar, A.H., A.K. Nurkhuraishah, M.N. Yusof, C.H. Pin, 2012. The Necessity of the Project Manager in Housing Development: Case Studies in Penang, Malaysia, World Applied Sciences Journal, 16 (10): 1462-1472

5. Heldman, K., V. Mangano, 2009. PMP Project Management Professional Exam Review Guide. John Wiley and Sons.

6. Salehi, M., 2009. Application of Fuzzy TOPSIS Technique for Evaluation of Project. World Applied Sciences Journal, 6 (6): 776-783

7. Soleimanzadeh, S., M.A. Othuman Mydin, 2013. Influence of High Temperatures on Flexural Strength of Foamed Concrete Containing Fly Ash and Polypropylene Fiber, International Journal of Engineering, 26 (1): 365-374.

8. Fahimifard, S.M., A.A. Kehkha, 2009. Application of Project Scheduling in Agriculture (Case Study: Grape Garden Stabilization). American-Eurasian J. Agric. \& Environ. Sci., 5 (3): $313-$ 321

9. Bolotin, S., A. Birjukov, 2013. Time Management in Drafting Probability Schedules for Construction Work. World Applied Sciences Journal 23: 1-4

10. Othuman Mydin, M.A., 2011. Thin-walled steel enclosed lightweight foamed concrete: A novel approach to fabricate sandwich composite. Australian Journal of Basic and Applied Sciences, 5 (12): 1727-1733 